\title{
Activation of Microglial Group III Metabotropic Glutamate Receptors Protects Neurons against Microglial Neurotoxicity
}

\author{
Deanna L. Taylor, ${ }^{1}$ Lara T. Diemel, ${ }^{2}$ and Jennifer M. Pocock ${ }^{1}$ \\ ${ }^{1}$ Cell Signalling Laboratory and ${ }^{2}$ Laboratory of Experimental Neuroinflammation, Department of Neuroinflammation, Institute of Neurology, \\ University College London, London, WC1N 1PJ, United Kingdom
}

\begin{abstract}
A reduction in microglial activation and subsequent neurotoxicity may prove critical for neuroprotection in neurodegenerative diseases. We examined the expression and functionality of group III metabotropic glutamate (mGlu) receptors on microglia. Rat microglia express mRNA and receptor protein for group III mGlu receptors mGlu4, mGlu6, and mGlu8 but not mGlu7. Activation of these receptors on microglia with the specific group III agonists $(L)$-2-amino-4-phosphono-butyric acid (L-AP-4) or $(R, S)$-phosphonophenylglycine $(R S$ PPG) inhibited forskolin-induced cAMP production, linking these receptors to the negative inhibition of adenylate cyclase. These agonists did not induce a fall in mitochondrial membrane potential or apoptosis in the microglia, suggesting that activation of these receptors is not in itself toxic to microglia. Fluorescence-activated cell sorting analysis revealed that activation of group III mGlu receptors induces a mild activation of the microglia, as evidence by their enhanced staining with ED1. However, this activation is not neurotoxic. Agonists of group III mGlu receptors reduced microglial reactivity when they were activated with lipopolysaccharide (LPS), chromogranin A (CGA) or amyloid $\beta$ peptide 25-35 (A $\beta 25-35$ ). Furthermore, L-AP-4 or RS-PPG treatment of microglia reduced their neurotoxicity after microglial stimulation with LPS or CGA but not $A \beta 25-35$. Similar results were obtained with microglial conditioned medium or in coculture, suggesting that the activation of microglial group III mGlu receptors may modulate the production of stable neurotoxins from the microglia. These results suggest that selective modulation of microglial group III mGlu receptors may provide a therapeutic target in neuroinflammatory diseases such as Alzheimer's disease.
\end{abstract}

Key words: neurodegenerative disease; Alzheimer’s disease; microglia; neurotoxicity; metabotropic glutamate receptors; neuroprotection

\section{Introduction}

Microglia, the resident macrophage of the brain, are increasingly implicated in the signaling cascades leading to neuronal death in a number of neurodegenerative diseases. Microglial overactivation may lead to their enhanced and neurotoxic production of a number of compounds that normally are important brain cell signaling molecules. One of these, glutamate, is a major determinant of microglial-evoked neurotoxicity (Piani et al., 1991, 1992; Patrizio and Levi, 1994) and can cause NMDA receptor-mediated toxicity to neurons in vitro (Piani et al., 1991; Piani and Fontana 1994; Klegeris and McGeer 1997; Klegeris et al., 1997; Kingham et al., 1999). Glutamate release from microglia occurs via the cystine-glutamate antiporter, as well as by a bafilomycin A-sensitive mechanism (Kingham et al., 1999). Overstimulation of microglia leads to microglial apoptosis, which may have consequences for the ability of the brain to recover from insult (Kingham et al., 1999; Kingham and Pocock, 2000; Liu et al., 2001). Thus, the regulation of microglial reactivity and neurotoxicity would seem

\footnotetext{
Received 0ct. 18, 2002; revised Dec. 18, 2002; accepted Dec. 20, 2002

We acknowledge support from the Brain Research Trust (United Kingdom) and the Wellcome Trust (United Kingdom) for this research. We thank Professor R. Shigemoto (National Institute for Physiological Sciences, Okazaki, Japan) for the gift of the mGlu6 receptor antibody. We thank Dr. David Kelly (Rayne Institute, University College London, London, UK) for help with the confocal microscopy and Dr. David Baker and Gareth Pryce (Institute of Neurology, University College London) for assistance with the FACS analysis.

Correspondence should be addressed to Dr. J. M. Pocock, Cell Signalling Laboratory, Department of Neuroinflammation, Institute of Neurology, University College London, 1 Wakefield Street, London, WC1N 1PJ, UK. E-mail: j.pocock@ion.ucl.ac.uk.

Copyright $\odot 2003$ Society for Neuroscience $\quad 0270-6474 / 03 / 232150-11 \$ 15.00 / 0$
}

desirous for neuroprotection in neurodegenerative diseases (Nicoletti et al., 1996).

Activation of microglia with chromogranin A (CGA), a secretory peptide with enhanced expression in Alzheimer's disease (Munoz et al., 1990; Munoz, 1991; Yasuhara et al., 1994), leads to a reactive neurotoxic microglial phenotype (Ciesielski-Treska et al., 1998) and causes microglial glutamate release (Kingham et al., 1999). This glutamate release is involved in an autologous feedback loop to damage the microglia (Kingham et al., 1999) and to trigger neurotoxin release by activation of group II metabotropic glutamate (mGlu) receptors on these cells (Taylor et al., 2002). Exposure of microglia to amyloid $\beta$ peptide 25-35 (A $\beta 25-35)$ also displays an underlying activation of group II mGlu receptors (Taylor et al., 2002). Furthermore, the direct stimulation of these receptors on microglia by specific agonists is also neurotoxic (Taylor et al., 2002).

Metabotropic glutamate receptors exist in at least eight subtypes, classified into three main groups according to pharmacological properties, signal transduction mechanisms, and gene sequence homology. Thus, group I includes mGlu1 and mGlu5, group II includes mGlu2 and mGlu3, and group III includes mGlu4, mGlu6, mGlu7, and mGlu8 (Pin and Duvoisin, 1995; Conn and Pin, 1997; Schoepp et al., 1999). To date, microglia have been shown to express mGlu5 (Biber et al., 1999), mGlu2, and mGlu3 (Taylor et al., 2002). Here we report that primary cultured rat microglia express mRNA and protein for group III mGlu receptors, which are negatively coupled to adenylate cyclase. However, unlike microglial group II mGlu receptors, microglial group III mGlu receptors are not positively coupled to 
the signaling cascade triggering microglial apoptosis activated after CGA, lipopolysaccharide (LPS), or A $\beta 25-35$ stimulation. Furthermore, stimulation of microglial group III mGlu receptors protected microglia after stimulation with CGA, LPS, or A $\beta 25-35$ and attenuated the subsequent neurotoxicity of microglia stimulated with CGA or LPS. These data suggest that mechanisms that promote the activation of group III mGlu receptors on microglia may provide therapeutic benefit in Alzheimer's disease and other neurodegenerative diseases in which microglial reactivity is implicated.

\section{Materials and Methods}

Materials. Fetal calf serum and minimum essential medium with Earle's salts were obtained from Invitrogen (Paisley, UK). Tissue culture plastic ware was obtained from Scientific Laboratory Supplies (Nottingham, UK). CGA was purchased from Scientific Marketing Associates (Hertfordshire, UK). All mGlu receptor agonists and antagonists, (L)-2amino-4-phosphono-butyric acid (L-AP-4), ( $R, S)$-phosphonophenylglycine (RS-PPG), and ( $S$ )-2-amino-2-methyl-4-phosphonobutanoic acid (MAP4) were from Tocris Cookson (Bristol, UK). A $325-35$ was from Bachem (St. Helens, UK).

Rabbit anti-mGlu4a IgG, rabbit anti-mGlu7 IgG, and rabbit antimGlu8 IgG were from Upstate Biotechnology (Buckingham, UK). AntimGlu4a was generated using a synthetic peptide corresponding to the C-terminal sequence amino acids 893-912. Anti-mGlu7 was generated using a synthetic peptide corresponding to the C-terminal sequence amino acids 899-912. Anti-mGlu8 was generated using a synthetic peptide corresponding to the C-terminal sequence amino acids 889-908. Rabbit polyclonal anti-mGlu6 antibody raised against a synthetic peptide corresponding to the C-terminal sequence (amino acid residues 853871) was a gift from Prof. R. Shigemoto (National Institute for Physiological Science, Okazaki, Japan). Anti-rat ED1:FITC and mouse anti-rat CD11b/MRC OX-42 were obtained from Serotec (Oxford, UK). Rabbitanti-mouse FITC-labeled antibody and goat anti-rabbit tetramethylrhodamine isothiocyanate (TRITC)-labeled antibodies were fromVector Laboratories (Burlingame, CA). Protein A/G-agarose was from Santa Cruz Biotechnology (Santa Cruz, CA) Immuno Fluore mounting medium was from ICN Biochemicals (Thame, UK). Reverse transcriptase, dNTPs, oligo-dT primer, and Moloney murine leukemia virus (MMLV) reverse transcriptase were from Invitrogen (Paisley, UK). TaqDNA polymerase and the $100 \mathrm{bp}$ DNA ladder were from Promega (Southampton, UK). All other chemicals were purchased from Sigma (Dorset, UK).

Preparation of primary cultures of microglia. Microglial cells were isolated from 3- to 6-d-old Wistar rat pups as described previously (Kingham and Pocock, 2000). Briefly, animals were killed by cervical dislocation and decapitation in accordance with the Scientific Procedures Act of 1986 (United Kingdom). Brains were removed into ice-cold PBS (in mм: $140 \mathrm{NaCl}, 5 \mathrm{KCl}, 25 \mathrm{Na}_{2} \mathrm{HPO}_{4}, 2.9 \mathrm{NaH}_{2} \mathrm{PO}_{4} \cdot 2 \mathrm{H}_{2} \mathrm{O}$, and 11 glucose, $\mathrm{pH}$ 7.4) and homogenized. The homogenate was centrifuged at $500 \times g$ for $10 \mathrm{~min}$, and the pellet resuspended in $70 \%$ isotonic Percoll diluted with PBS. This was overlaid with $35 \%$ Percoll and then PBS. The Percoll gradient was centrifuged at $1250 \times g$ for $45 \mathrm{~min}$, and cells were collected from the $35 / 70 \%$ interface. After washing, the cells were plated at $6 \times 10^{4}$ per $13 \mathrm{~mm}$ coverslip or $4.5 \times 10^{5}$ on $32 \mathrm{~mm}$ coverslips for lysates. Cultures were maintained at $37^{\circ} \mathrm{C}$ in $5 \% \mathrm{CO}_{2}$ in minimum essential medium with Earle's salts supplemented with $25 \mathrm{~mm} \mathrm{KCl}, 30 \mathrm{~mm}$ glucose, $25 \mathrm{~mm} \mathrm{NaHCO}, 1 \mathrm{~mm}$ glutamine, $10 \%$ fetal calf serum, $50 \mathrm{U} / \mathrm{ml}$ penicillin, and $50 \mu \mathrm{g} / \mathrm{ml}$ streptomycin. This medium was used to culture the microglia because this was the same medium in which cultured cerebellar granule neurons were grown and allows us to add conditioned medium from the microglia to the neurons. In particular, adding conditioned medium with a reduced $\mathrm{KCl}$ concentration would be detrimental to the survival of cerebellar granule neurons. Cells were routinely used $1 \mathrm{~d}$ after plating. We confirmed our previous findings that, after $1 \mathrm{~d}$ in vitro (1 DIV), microglial cells exhibit a resting, ramified morphology with only a small number of cells staining positive for ED1 (a marker for activated microglia) and that cultures were enriched with microglia with few con- taminating cells as shown by positive immunoreactivity to the microglial marker OX-42 (data not shown) (Kingham et al., 1999).

Preparation of primary cultures of neurons. Cerebellar granule neurons were isolated from 3- to 6-d-old rat pups and prepared as described previously (Evans and Pocock, 1999). Cells were plated on $13 \mathrm{~mm}$ polyD-lysine-coated glass coverslips at a density of $0.65 \times 10^{6}$ per coverslip and maintained in minimum essential medium (as above). After $24 \mathrm{hr}$ in vitro, cytosine furanoarabinoside $(10 \mu \mathrm{M})$ was added to prevent proliferation of non-neuronal cells. The cultures were maintained at $37^{\circ} \mathrm{C}$ in $5 \%$ $\mathrm{CO}_{2}$ and were used after $7 \mathrm{~d}$ in vitro.

Treatment of microglial cultures. Microglial cells were exposed to mGlu receptor agonists and/or antagonists together with CGA (50 nM), LPS (1 $\mu \mathrm{g} / \mathrm{ml})$, or $\mathrm{A} \beta 25-35$ (50 $\mu \mathrm{M})$ to the culture medium, to mGlu receptor agonists-antagonists alone, or to CGA, LPS, or A $\beta 25$-35 alone. The concentrations of specific $\mathrm{mGlu}$ receptor agonists and antagonists used were as follows: $100 \mu \mathrm{M} \mathrm{L}-\mathrm{AP}-4,100 \mu \mathrm{M} R S$-PPG, and $500 \mu \mathrm{M}$ or $2 \mathrm{~mm}$ MAP4. Microglia were incubated for $24 \mathrm{hr}$ with CGA before tissue culture medium was collected, and the cells were evaluated for apoptosis.

Isolation of total RNA. Total RNA was isolated from primary cultured microglia by guanidine thiocyanate lysis and phenol-chloroform extraction (Chomczynski and Sacchi, 1987). The yield of total RNA was quantified by optical density readings at $260 \mathrm{~nm}$, and the purity was estimated by the $260 / 280 \mathrm{~nm}$ ratio.

Glutamate receptor $m R N A$ expression by reverse transcription-PCR. Equivalent amounts of total RNA ( $2 \mu \mathrm{g}$ ) from microglial preparations were reverse transcribed into single-stranded cDNA in a reaction mixture containing $10 \mathrm{~mm}$ dithiothreitol, $40 \mathrm{U}$ of RNase inhibitor, $10 \mathrm{~mm}$ Tris-HCl, pH 8.3, 15 mu KCl, 0.6 mm $\mathrm{MgCl}_{2}, 0.5 \mathrm{~mm}$ dNTPs, $250 \mathrm{ng}$ of oligo-dT primer, and $600 \mathrm{U}$ of MMLV reverse transcriptase at $37^{\circ} \mathrm{C}$ for 80 min. Incubation for $10 \mathrm{~min}$ at $70^{\circ} \mathrm{C}$ terminated the reverse transcription reaction. All samples from individual experiments were reverse transcribed simultaneously. Negative controls were prepared by incubation of samples without reverse transcriptase.

PCR was performed on the equivalent of $100 \mathrm{ng}$ of reverse-transcribed total RNA from each sample as described previously (Copelman et al., 2000). A PerkinElmer Life Sciences (Warrington, UK) thermocycler was used with a reaction mixture containing $50 \mathrm{~mm} \mathrm{KCl}, 10 \mathrm{~mm}$ Tris- $\mathrm{HCl}, \mathrm{pH}$ 9, $0.1 \%$ Triton X-100, $0.5 \mathrm{~mm} \mathrm{MgCl}_{2}, 200 \mu \mathrm{M}$ dNTPs, $1 \mu \mathrm{M}$ each of upstream and downstream primer, and $2.5 \mathrm{U}$ of TaqDNA polymerase. Complementary DNA sequences were obtained from the nucleotide sequence database GenBank (National Center of Biotechnology Information, Bethesda, MD), and the resulting PCR primer sequences (Operon Europe, Cologne, Germany), accession numbers, $\mathrm{MgCl}_{2}$ concentrations, and optimal annealing temperatures (OAT) were as follows: (1) mGlu4: accession number $\mathrm{M} 90518 ; 1 \mathrm{~mm} \mathrm{MgCl}_{2}$; OAT of $59^{\circ} \mathrm{C}$; upstream, $5^{\prime}$ TGAGCTACGTGCTGCTGGCG-3'; downstream, 5' ${ }^{\prime}$-TGTCGGCTGACTGTGAGGTG-3'; (2) mGlu6: accession number D13963; 1.5 mM $\mathrm{MgCl}_{2}$; OAT of $53^{\circ} \mathrm{C}$; upstream, $5^{\prime}$-CAAGTAGCAAGGTTGAGTGT-3'; downstream, 5' -GGTTGTAGTGTTGGATCAAG-3'; (3) mGlu7: accession number D16817; $1.5 \mathrm{~mm} \mathrm{MgCl}_{2}$; $\mathrm{OAT}$ of $53^{\circ} \mathrm{C}$; upstream, $5^{\prime}$-GAACTCTGTGAAAATGTAGACC-3'; downstream, 5' -TTAGGGAGTCCAGAATTACAG-3'; (4) mGlu8: accession number U63288; $1.5 \mathrm{~mm}$ $\mathrm{MgCl}_{2}$; OAT of $53^{\circ} \mathrm{C}$; upstream, 5' -GAGGGTTATAACTACCAGGT-3'; downstream, 5' -TAGGTGCTGTGACAGATTTCT-3'; and (5) GAPDH: accession number $\mathrm{M} 17701 ; 2 \mathrm{~mm} \mathrm{MgCl}_{2}$; $\mathrm{OAT}$ of $60^{\circ} \mathrm{C}$; forward primer, 5'-TGGTGCCAAAAGGGTCATCATCTCC-3'; reverse primer, 5' -GCCAGCCCCAGCATCAAAGGTG-3'.

Wherever possible, primer pairs were designed to span an intron boundary to obviate DNase treatment of total RNA before reverse transcription (RT)-PCR. PCR performed on non-reverse-transcribed total RNA samples did not produce any detectable products. The thermal cycle profile for each set of primers included a primary denaturation cycle at $94^{\circ} \mathrm{C}$ for $5 \mathrm{~min}$ and a final extension period at $72^{\circ} \mathrm{C}$ for $10 \mathrm{~min}$. The intervening PCR cycle consisted of 1 min segments of primer denaturation, annealing, and extension and was repeated for 40 cycles for each primer pair.

Equivalent amounts $(20 \mu \mathrm{l})$ of each PCR product were size fractionated on a $1 \%$ agarose gel, and the product size was verified by running the samples against a $100 \mathrm{bp}$ DNA ladder. The PCR products were visualized 
by staining the agarose gels with $0.5 \mu \mathrm{g} / \mathrm{ml}$ ethidium bromide and viewing under ultraviolet light.

Immunoprecipitation and Western blot analysis. Cells on coverslips were lysed by the addition of $20 \mu \mathrm{l}$ of radioimmunoprecipitation assay (RIPA) lysis buffer ( $1 \mathrm{~mm}$ benzamidine, $4 \mu \mathrm{g} / \mathrm{ml}$ leupeptin, $150 \mathrm{~mm}$ $\mathrm{NaCl}, 1 \% \mathrm{NP}-40,0.5 \%$ sodium deoxycholate, $0.1 \%$ SDS, and $50 \mathrm{~mm}$ Tris, $\mathrm{pH}$ 7.5) (McDonald et al., 1997) and incubated on ice for $4 \mathrm{hr}$. Samples were then centrifuged for $10 \mathrm{~min}$ at 10,000 rpm, and the supernatant containing the solubilized proteins was retained and assayed for protein concentration. RIPA buffer lysates containing $500 \mu \mathrm{g}$ of protein were then precleared by incubation with $10 \mu \mathrm{l}$ of resuspended volume of Protein A/G-agarose for $30 \mathrm{~min}$ at $4^{\circ} \mathrm{C}$. Samples were then centrifuged for $1 \mathrm{~min}$, and the supernatant was collected into a fresh tube. Primary antibody (10 $\mu \mathrm{g}$ antibody $/ 500 \mu \mathrm{l}$ sample) was added, and samples were incubated for $1 \mathrm{hr}$ at $4^{\circ} \mathrm{C}$ with end-over-end rotation. Subsequently, 20 $\mu \mathrm{l}$ of resuspended volume of Protein A/G-agarose was added, and incubation was continued overnight with rotation. The pellet was then collected by centrifugation and washed four times in fresh RIPA buffer, each time repeating the centrifugation step. After the final wash, the supernatant was removed and the pellet was resuspended in Lamaelli's sample buffer. Samples were then resolved on a 10\% SDS-polyacrylamide gel (Bio-Rad Hertfordshire, UK) and transferred to Immobilon P polyvinylidene difluoride (PVDF) membrane (Taylor et al., 2002). After blocking [ $2 \mathrm{hr}$ at room temperature with $2.5 \% \mathrm{BSA}$ in $10 \mathrm{~mm}$ Tris- $\mathrm{HCl}$ containing $150 \mathrm{~mm} \mathrm{NaCl}$ and $0.1 \%$ Tween 20 (T-TBS), pH 7.4], the membrane was incubated with the primary antibody for $4 \mathrm{hr}$ (mGlu4a, mGlu6, mGlu7, and mGlu8, all at 1:2000 in 2.5\% BSA) at room temperature and then repeatedly washed in T-TBS before being exposed to a horseradish peroxidase-conjugated secondary antibody ( $1: 2000$ in $2.5 \%$ BSA for $2 \mathrm{hr}$ at room temperature). After washing, blots were developed by enhanced chemiluminescence detection.

Immunocytochemical detection of $m G l u$ receptors. Cells were fixed in $100 \%$ cold methanol $\left(-20^{\circ} \mathrm{C}\right)$ for $20 \mathrm{~min}$, followed by one wash in PBS and preincubated for $30 \mathrm{~min}$ at $37^{\circ} \mathrm{C}$ in PBS containing $1 \%$ BSA. Cells were then incubated for $1 \mathrm{hr}$ at room temperature with primary antibody (mGlu4a, mGlu6, mGlu7, or mGlu8, at 1:40 in PBS plus 10\% BSA). After this, cells were incubated for $1 \mathrm{hr}$ at room temperature with primary antibody for OX-42 (1:1000). After washing, cells were exposed to goat anti-rabbit TRITC-conjugated antibody (1:100) and rabbit anti-mouse FITC-conjugated antibody (1:100) for $1 \mathrm{hr}$ at room temperature. In all cases, negative controls were treated in the same way, but the primary antibody was omitted. In addition to OX-42 staining to identify the microglia, we also stained cultures with FITC-labled Griffonia simplicifolia isolectin B4-(GSA-IB4) (1:20) (Streit, 1990). As a control for lectin binding, lectin was bound with $500 \mathrm{~mm}$ D-galactose in HEPES with 0.1 $\mathrm{mM} \mathrm{CaCl}_{2}$ for $30 \mathrm{~min}$ at room temperature before exposure to the cells at the same concentration. After washing, cells were briefly exposed to 1:1000 4,5-diamidino-2-phenylindole (DAPI) to stain the nuclei. Cells were mounted in Immuno Fluore mounting medium and observed by scanning confocal microscopy (Bio-Rad Radiance 2000; Bio-Rad, Hemel Hempstead, UK). For all different antibody staining, fluorescence images were obtained using the same focal plane and instrument gain. For the lectin or OX-42 staining, positive cells were counted in three separate fields on four coverslips per condition and expressed as a mean percentage of total cell number (DAPI positive). Of these positive cells, the number of cells expressing staining for mGlu receptors was then determined in the same fields.

Flow cytometry. Microglial expression of ED1, a marker of microglial activation, was assessed using the Becton Dickinson Immunocytometry Systems FACSCalibur modular flow cytometer. Briefly, microglial cells $(\sim 600,000)$ exposed to the mGlu receptor agonists CGA (100 nM) or LPS $(1 \mu \mathrm{g} / \mathrm{ml})$ for $24 \mathrm{hr}$ were harvested and centrifuged. The pellet was resuspended in PBS containing 4\% formaldehyde and $0.01 \%$ Triton X-100 and were incubated for $30 \mathrm{~min}$ at room temperature. Samples were then centrifuged, and the pellets were resuspended in $10 \mu \mathrm{l}$ of mouse anti-rat ED1:FITC at $0.1 \mathrm{mg} / \mathrm{ml}$ and incubated in the dark for $1 \mathrm{hr}$ at room temperature. Samples were then pelleted and resuspended in $750 \mu \mathrm{l}$ of sheath fluid (Becton Dickinson, Oxford, UK) before analysis by flow cytometry according to the instructions of the manufacturer. For each sample, 10,000 cells were counted, and the data were analyzed using CELLQUEST software (Becton Dickinson, Oxford, UK). Results were expressed as the percentage of cells fluorescent above a no-antibody control (percentage of positive events) and the logarithmic average of these values (mean fluorescence intensity).

Measurement of $c A M P$. Microglial cultures were treated with $1 \mathrm{~mm}$ 3-isobutyl-1-methylxanthine, an inhibitor of cAMP degeneration, for 10 min before the addition of forskolin $(100 \mu \mathrm{M})$. The cells were incubated for 10 min before exposure to RS-PPG $(100 \mu \mathrm{M})$ or L-AP-4 (100 $\mu \mathrm{M})$ with or without $500 \mu \mathrm{M}$ or $2 \mathrm{~mm}$ MAP4, for an additional $10 \mathrm{~min}$. When used, pertussis toxin (PTX) at $1 \mu \mathrm{g} / \mathrm{ml}$ was preincubated with the microglia for $22 \mathrm{hr}$ before the addition of forskolin and mGlu receptor agonists. cAMP production in these cells was compared with cells treated with forskolin alone and in untreated control cultures. Cells were lysed with $0.1 \mathrm{M} \mathrm{HCl}$ at room temperature for $15 \mathrm{~min}$, and cAMP was measured in cell supernatants using an enzyme immunoassay kit (Biomol, Affiniti Research Products, Plymouth Meeting, PA) according to the instructions of the manufacturer for the acetylated method.

Treatment of neuronal cultures. Conditioned medium from control and treated microglia was subsequently transferred to cerebellar granule cell cultures, which were then incubated for an additional $24 \mathrm{hr}$ before cells were fixed with $4 \%$ paraformaldehyde and neuronal apoptotic cell death quantified with Hoechst 33342 staining (Kingham et al., 1999).

Cocultures. Microglial cells (two coverslips) were placed in a $35 \mathrm{~mm}$ Petri dish in $2 \mathrm{ml}$ of medium, and mGlu receptor agonists-antagonists and/or CGA or LPS were added as described above. Twenty-four hours later, neuronal cells (two coverslips) were added to each dish, and the preparation was maintained at $37^{\circ} \mathrm{C}$ in $5 \% \mathrm{CO}_{2}$ for an additional $24 \mathrm{hr}$. Cells were then fixed, and apoptosis was assessed with Hoechst 33342 staining. Control cultures consisted of microglia alone, neurons alone, or nonstimulated microglia with neurons.

Measurement of microglial mitochondrial membrane polarization. Microglial mitochondrial membrane polarization $\left(\Delta \psi_{\mathrm{m}}\right)$ was assessed with the fluorescent probe JC-1. At $490 \mathrm{~nm}$, cells with depolarized mitochondria contained JC-1 predominantly in the monomeric form and fluoresced green. Cells with polarized mitochondria predominantly contained JC-1 in aggregate form, and the mitochondria fluoresced redorange (Salvioli et al., 1997). We showed previously that the state of mitochondrial depolarization as determined with JC-1 staining is the same as results obtained after staining with tetramethylrhodamine ethyl ester, another mitochondrial membrane potential-sensitive fluorescence dye, and that the fluorescence associated with either stain subsequently decreases in the microglial mitochondria after addition of the mitochondrial uncoupler carbonyl cyanide $p$-trifluoromethoxyphenylhydrazone (Kingham and Pocock, 2000). Microglia were incubated with JC-1 (5 $\mu \mathrm{M}$ ) in basic medium [ $153 \mathrm{~mm} \mathrm{NaCl}, 3.5 \mathrm{~mm} \mathrm{KCl}, 0.4 \mathrm{~mm} \mathrm{KH_{2 }} \mathrm{PO}_{4}, 20$ mM $n$-tris(hydroxymethyl)methyl-2-aminoethanesulphonic acid, $5 \mathrm{~mm}$ $\mathrm{NaHCO}_{3}, 5 \mathrm{~mm}$ glucose, $1.2 \mathrm{~mm} \mathrm{Na}_{2} \mathrm{SO}_{4}$, and $\left.1.3 \mathrm{~mm} \mathrm{CaCl}_{2}, \mathrm{pH} 7.4\right]$ at $37^{\circ} \mathrm{C}$ for $10 \mathrm{~min}$, washed, and placed on a thermostatted stage at $37^{\circ} \mathrm{C}$. Coverslips were viewed using an Olympus Optical (Tokyo, Japan) IX70 inverted fluorescence microscope with excitation at $490 \mathrm{~nm}$ and emission at $>520 \mathrm{~nm}$. Microglia with polarized mitochondria were seen with distinct mitochondria fluorescing red-orange, and, in microglia with depolarized mitochondria, the cell cytoplasm and mitochondria appeared green (Kingham and Pocock, 2000). The numbers of cells with mitochondria stained red-orange or green were counted, and the degree of mitochondrial depolarization was expressed as the percentage of green cells per field. A minimum of six fields per coverslip were counted, and between 6 and 10 coverslips from three independent experiments were assessed for each variable.

Assessment of apoptosis. After measurement of mitochondrial polarization, the same cells were then fixed with $4 \%$ paraformaldehyde in PBS $\left(4^{\circ} \mathrm{C}\right)$ for $10 \mathrm{~min}$ and then incubated with Hoechst $33342(5 \mu \mathrm{g} / \mathrm{ml})$ for 10 min (Yan et al., 1994; Kingham et al., 1999). Nuclear morphology was viewed using a fluorescence microscope with excitation at $360 \mathrm{~nm}$ and emission at $>490 \mathrm{~nm}$. Apoptotic cells were identified as those cells containing brightly stained pyknotic nuclei compared with healthy cells in which the nuclei appeared less bright and less condensed. A minimum of 


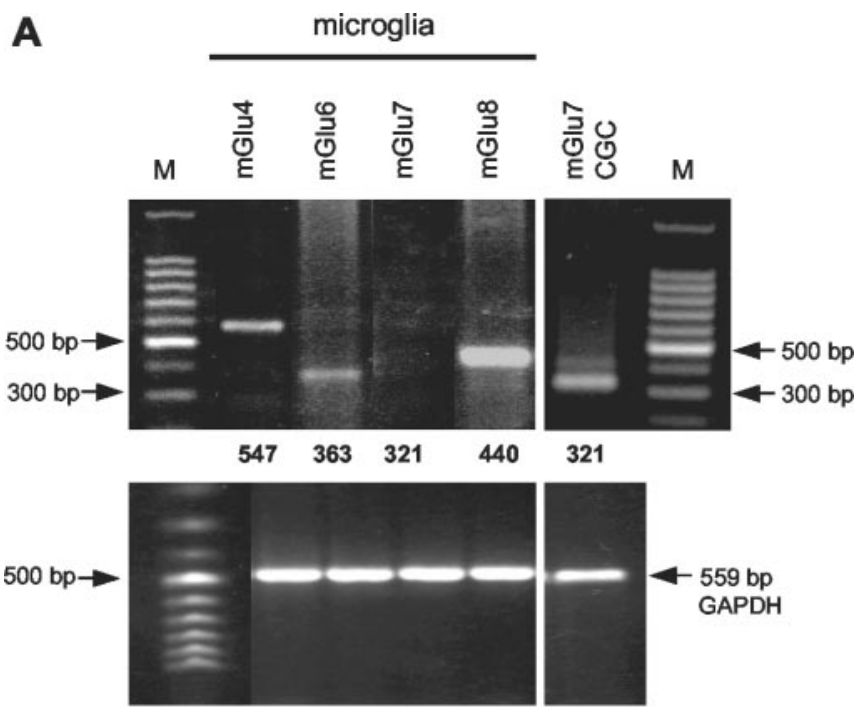

B i mGlu4a

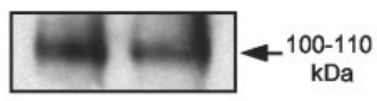

iii mGlu7

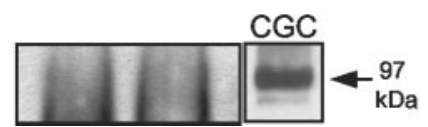

ii mGlu6

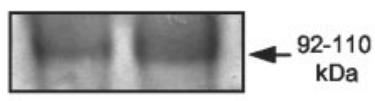

iv mGlu8

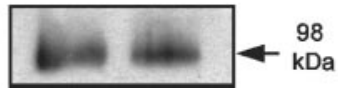

Figure 1. Microglia express mRNA and receptor protein for mGlu4, mGlu6, and mGlu8 but not mGlu7. A, Ethidium bromide-stained gel of mGlu4, mGlu6, mGlu7, and mGlu8 RT-PCR products derived from the equivalent of $100 \mathrm{ng}$ of total RNA extracted from primary cultured rat microglia. Equal amounts of each PCR product were size fractionated on a $1 \%$ agarose gel, and a $100 \mathrm{bp}$ DNA ladder marker $(M)$ was run where the brightest band is equal to $500 \mathrm{bp}$. PCR product sizes are 547, 363, 321, and 440 bp for mGlu4, mGlu6, mGlu7, and mGlu8, respectively. As a positive control for mGlu7, an equivalent amount of RNA was extracted from 12 DIV cultured cerebellar granule cells ( $m$ Glu7 CGC). GAPDH expression (559 bp) in an equivalent amount of RNA is shown below for each of the above lanes. $B$, Western blot of cell lysates from primary cultured rat microglia subjected to immunoprecipitation with anti-mGlu4a (i), anti-mGlu6 (ii), anti-mGlu7 (iii), or anti-mGlu8 (iv) (all immunoprecipitated at $10 \mu \mathrm{g}$ antibody/500 $\mu \mathrm{l} \mathrm{sam-}$ ple). The immunoprecipitates were resolved by $10 \%$ SDS-PAGE, transferred to PVDF membrane, and blotted against the same antibody at 1:2000. Predicted molecular weights for the receptor subunits are given to the right of each blot; mGlu4a, 100-110 kDa; mGlu6, 92-110 kDa; mGlu7, $97 \mathrm{kDa}$; and mGlu8, $98 \mathrm{kDa}$. As a positive control for mGlu7, an equivalent amount of protein from 12 DIV cultured cerebellar granule cells was subjected to immunoprecipitation and blotting (Biii; CGC).

six fields per coverslip were counted, and between 6 and 10 coverslips were assessed for each variable.

\section{Results}

Microglia express mRNA for mGlu4, mGlu6, and mGlu8 but not mGlu7

RT-PCR analysis revealed that primary cultured rat microglia express single-band amplification products of the expected sizes for mGlu4 (547 bp), mGlu6 (363 bp), and mGlu8 (440 bp) (Fig. $1 A)$. We were unable to detect a band at the predicted size (321 bp) for mGlu7. To check our primers and protocol, we ran a positive control for mGlu7 using 12 DIV cultured cerebellar granule neurons, which have been shown previously to express mRNA for this subtype (Janssens and Lesage, 2001). The cerebellar cultures expressed a strong band at the predicted size. In the microglia, the strongest expression was observed for mGlu8. The expression of the housekeeping gene GAPDH was equal across all lanes, suggesting that the above differences are not attributable to differential loading.

\section{Microglia express receptor protein for mGlu4a, mGlu6, and mGlu8}

Immunoprecipitation and Western blotting of mGlu4a, mGlu7, and mGlu8 were performed using commercial antibodies. Detection of receptor protein for mGlu6 was determined with a polyclonal antibody from Prof. R. Shigemoto (Shigemoto et al., 1997). Western blotting of primary microglia revealed a prominent band at the predicted molecular weight of $100-110 \mathrm{kDa}$ for mGlu4a (Fig. 1 Bi). For mGlu6, a prominent band at the predicted molecular weight of $92-110 \mathrm{kDa}$ was detected (Fig. 1 Bii). For mGlu7, no obvious bands at the predicted molecular weight of $97 \mathrm{kDa}$ were detected (Fig. $1 \mathrm{Biii}$ ). A positive control for mGlu7 receptor protein was therefore performed using 12 DIV cerebellar granule neurons (Fig. 1 Biii). Western blotting for mGlu8 revealed a prominent band at the predicted molecular weight of 98 kDa (Fig. 1Biv).

Immunolocalization of the mGlu receptors on the microglia was performed using commercially available antibodies for mGlu4a, mGlu7, and mGlu8 and an antibody to mGlu6 provided by Prof. R. Shigemoto, colocalized with the microglial marker OX-42 (Fig. 2). Controls in which primary antibody for the mGlu receptors was omitted did not show any fluorescence labeling for the mGlu receptors. Immunolocalization and Western blotting revealed staining and protein bands for mGlu4a, mGlu6, and mGlu8 but not mGlu7, reflecting the mRNA expression results. Analysis of the number of cell in the microglial cultures staining with the lectin GSA-IB4 revealed that an average of $99.05 \pm$ $0.95 \%$ of the cells per field stained with this microglial marker (Streit, 1990). This was not significantly different from the number of cells stained with OX-42 (98.97 $\pm 1.22 \%)$. Of these, $93 \%$ of the cells stained with antibody to mGlu4a, $97 \%$ with antibody to mGlu6, $0.87 \%$ with antibody to mGlu7, and $92 \%$ with antibody to mGlu8 (Table 1, top).

Functional coupling of group III mGlu receptors on microglia with second messengers

Because the activation of group III mGlu receptors is coupled to inhibition of adenylate cyclase for other cell types, we sought to determine whether this was also true for microglial mGlu receptors. Thus, the ability of group III mGlu receptor agonists to inhibit forskolin-induced cAMP accumulation was assessed. We found that the group III mGlu receptor agonists RS-PPG (100 $\mu \mathrm{M})$ or L-AP-4 (100 $\mu \mathrm{M})$ both significantly reduced forskolininduced CAMP accumulation in primary rat cultured microglia (Fig. 3). This effect was significantly reversed by coexposure to the group III mGlu receptor antagonist MAP4; interestingly, reversal of the L-AP-4 inhibition required a concentration of $2 \mathrm{mM}$ MAP4, whereas either $500 \mu \mathrm{M}$ or 2 mM MAP4 reversed $R S-P P G$ inhibition of forskolin-induced cAMP production (Fig. 3). Furthermore, the inhibition of cAMP accumulation by the specific group III mGlu receptor agonists could be abolished by pretreatment of the microglia for $22 \mathrm{hr}$ with pertussis toxin, suggesting the upstream modulation by PTX sensitive G-proteins (Fig. 3). 


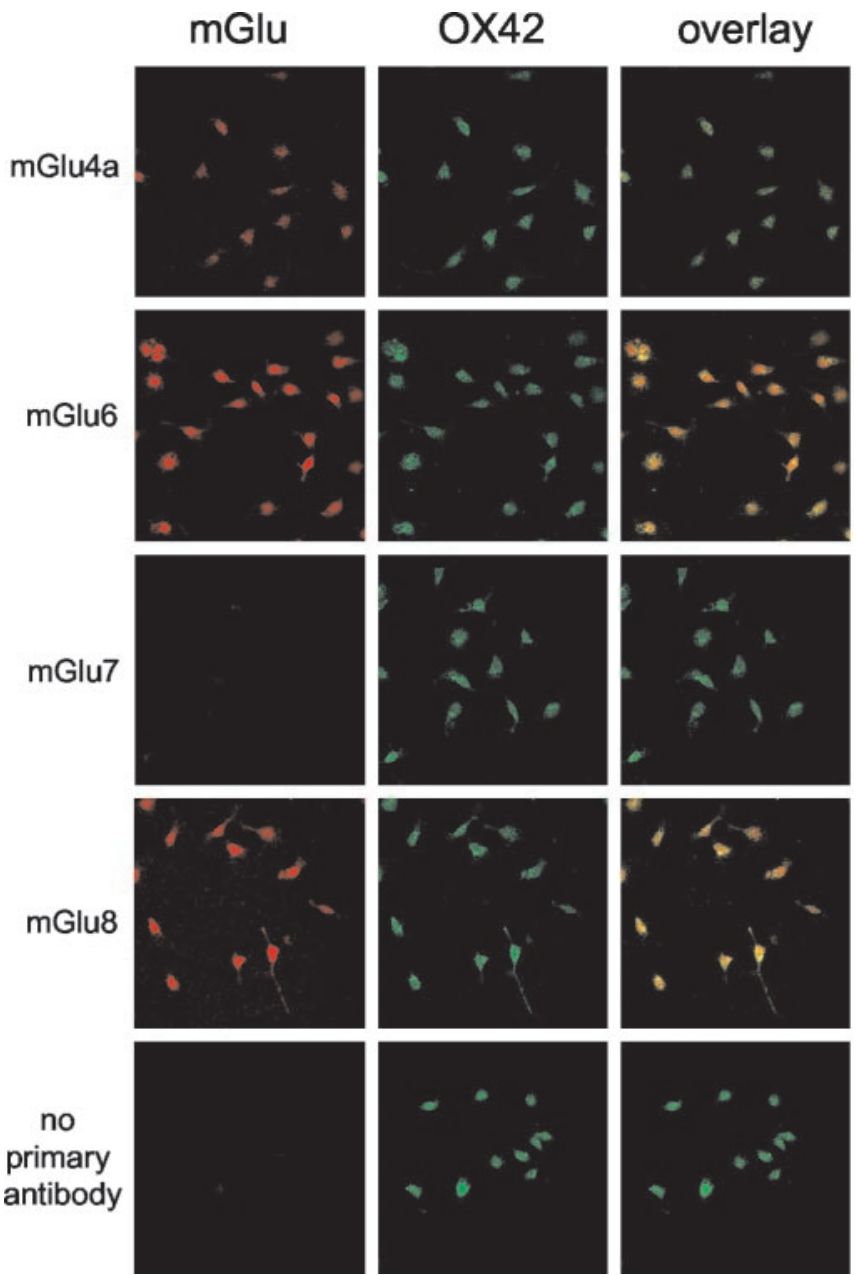

Figure 2. Colocalization of group III mGlu receptor protein with $0 X-42$, a marker for microglia. Immunolocalization of mGlu4a, mGlu6, mGlu7, and mGlu8 in primary cultured nonstimulated microglia. The negative control without primary antibody for mGlu receptors is also shown. Column marked OX42 shows staining with antibody to $0 X-42$, a specific microglial marker for the respective fields to the left. overlay indicates the combined fluorescence from the same field stained with antibody to $\mathrm{mGlu}$ receptor and $0 \mathrm{X}-42$.

\section{Stimulation of microglial group III mGlu receptors} does not trigger microglial apoptosis and prevents activation-induced apoptosis

Because the presence of functional group III mGlu receptors on microglia may have consequences for microglial reactivity when they are exposed to elevated external glutamate, we determined how activation of these receptors may modulate microglial reactivity and subsequent neurotoxicity. We showed previously that, when microglia become activated, they may also become stressed, as evidenced by mitochondrial depolarization; ultimately, the microglia become apoptotic (Kingham et al., 1999; Kingham and Pocock, 2000). Microglial apoptosis as a consequence of activation has also be shown for other activators of microglia (Liu et al., 2001). We showed recently that stimulation of group II mGlu receptors on microglia can induce microglial apoptosis (Taylor et al., 2002). We thus investigated the consequences of stimulation of microglial group III mGlu receptors on microglial mitochondrial membrane potential $\left(\Delta \Psi_{\mathrm{m}}\right)$ and apoptosis.

A $24 \mathrm{hr}$ exposure to the group III receptor agonists L-AP-4 $(100 \mu \mathrm{M})$ or $R S-\mathrm{PPG}(100 \mu \mathrm{M})$ alone or in combination with the group III receptor antagonist MAP4 (2 mM) did not trigger a fall
Table 1. Immunostaining of microglia to $\mathrm{mGlu}$ receptors and activation markers

Percentage of total number of cells in control microglial cultures staining with markers

Isolectin B4 $\quad 99.05 \pm 0.95$

OX-42 $\quad 98.97 \pm 1.22(p=0.9600)$

mGlu4a $\quad 92.83 \pm 1.84(p=0.0305)$

mGlu6 $\quad 97.11 \pm 0.19(p=0.1896)$

mGlu7 $\quad 0.87 \pm 0.54(p<0.0001)$

mGlu8 $\quad 91.84 \pm 3.78(p=0.2280)$

Percentage of total number of cells staining with ED1

$\begin{array}{lr}\text { Control } & 2.93 \pm 0.69 \\ \text { L-AP-4 } & 36.60 \pm 0.01 \\ \text { RS-PPG } & 38.65 \pm 3.89 \\ \text { CGA } & 77.80 \pm 4.70\end{array}$

FACS data for the percentage of cells staining with ED1

\begin{tabular}{llc} 
& \% Positive events & Mean fluorescence intensity \\
Control & 16.66 & 9.22 \\
L-AP-4 & 30.39 & 9.69 \\
RS-PPG & 32.05 & 10.58 \\
CGA & 50.10 & 29.87 \\
LPS & 69.29 & 24.46 \\
\hline
\end{tabular}

Top, Percentage of cells staining with isolectin B4, 0X-42, and antibodies to mGlu4a, mGlu6, mGlu7, and mGlu8 receptors. Primary cultured microglia were fixed after 1 DIV and stained with Griffonia simplicifolia isolectin B4 (1:20) or 0X-42 (1:1000) and mGlu4a, mGlu6, mGlu7, or mGlu8 antibodies (all at 1:250) and counterstained with DAPI (1:1000) for total cell number. Cells were counted in three separate fields on four coverslips per condition and expressed as a mean \pm SEM percentage of total cell number (DAPI-positive cells). $p$ values are given for comparison by ANOVA, followed by pairwise analysis by Student's $t$ test with isolectin B4 staining.

Middle, Percentage of cells staining with ED1, a microglial marker for activation. Primary microglial cultures were treated for $24 \mathrm{hr}$ with $100 \mu \mathrm{m} \mathrm{L-AP-4,} 100 \mu \mathrm{M} R S$-PPG, or $50 \mathrm{~nm}$ (GA or solvent only (controls). Cells were fixed and stained with ED1 (1:500) and counterstained with hematoxylin. Cells were counted in three separate fields on four coverslips per condition, and the number of ED1-positive cells are expressed as a percentage of total cell number (hematoxylin-positive cells). Mean \pm SEM of three separate fields on four coverslips per condition.

Bottom, FACS analysis for the percentage of cells staining with ED1 after exposure of microglial cultures to mGlu receptor agonists and activators. Primary cultured microglia were treated for $24 \mathrm{hr}$ with $100 \mu \mathrm{M} \mathrm{L-AP}-4,100 \mu \mathrm{M}$ RS-PPG, $50 \mathrm{~nm} \mathrm{CGA,} 1 \mu \mathrm{g} / \mathrm{ml}$ LPS, or solvent only (controls). Cells were fixed and incubated with ED1:FITC (0.1 $\mathrm{mg} / \mathrm{ml}$ ) and subjected to FACS analysis. Ten thousand cells per sample were counted, and results are expressed as the percentage of cells fluorescent above a no-antibody control (\% Positive events) and the logarithmic average of these values also obtained (Mean fluorescence intensity).

in microglial $\Delta \Psi_{\mathrm{m}}$ or an increase in apoptosis above control levels (Fig. 4A). MAP4 at $500 \mu \mathrm{M}$ did not trigger a fall in microglial $\Delta \Psi_{\mathrm{m}}$ or apoptosis either alone or in combination with either L-AP-4 or RS-PPG (data not shown). Microglia exposed to L-AP-4 or RS-PPG for $24 \mathrm{hr}$ became immunoreactive for ED1, as determined by immunolocalization (Table 1 , middle) or fluorescence-activated cell sorting (FACS) (Table 1, bottom), although this was significantly less than in microglia after activation with CGA or LPS for $24 \mathrm{hr}$. The ED1 staining in microglia exposed to L-AP- 4 or RS-PPG did not significantly increase at 48 $\mathrm{hr}$, and there was no increase in apoptosis above control at this time point (data not shown).

As shown previously, CGA induced a fall in microglial $\Delta \Psi_{\mathrm{m}}$ leading to apoptosis (Kingham and Pocock, 2000; Taylor et al., 2002) (Fig. 4B). L-AP-4 or RS-PPG significantly reduced CGAinduced microglial mitochondrial depolarization and apoptosis to control levels (Fig. 4B). The effects of L-AP-4 or RS-PPG on CGA-induced $\Delta \Psi_{\mathrm{m}}$ and apoptosis in the microglia were reversed by $500 \mu \mathrm{M}$ MAP4 in the case of RS-PPG. We found that a higher concentration of MAP4 ( $2 \mathrm{mM}$ ) was required to reverse the effect of L-AP-4. Thus, the percentage of CGA-induced apoptosis $(39.43 \pm 2.37 \%$ cells per field) was reduced to $4.67 \pm 2.12 \%$ by L-AP-4. This inhibition of CGA-induced apoptosis could be reversed to $16.77 \pm 3.26 \%$ with 1 mM MAP4 or $35.20 \pm 5.24 \%$ with 2 mM MAP4. It is likely that these higher concentration of MAP4 are required to reverse the effect of $\mathrm{L}-\mathrm{AP}-4$ because of the structural similarities between these two compounds (Conn and Pin, 1997; Schoepp et al., 1999). In all cases, therefore, $500 \mu \mathrm{M}$ MAP4 


\section{forskolin}

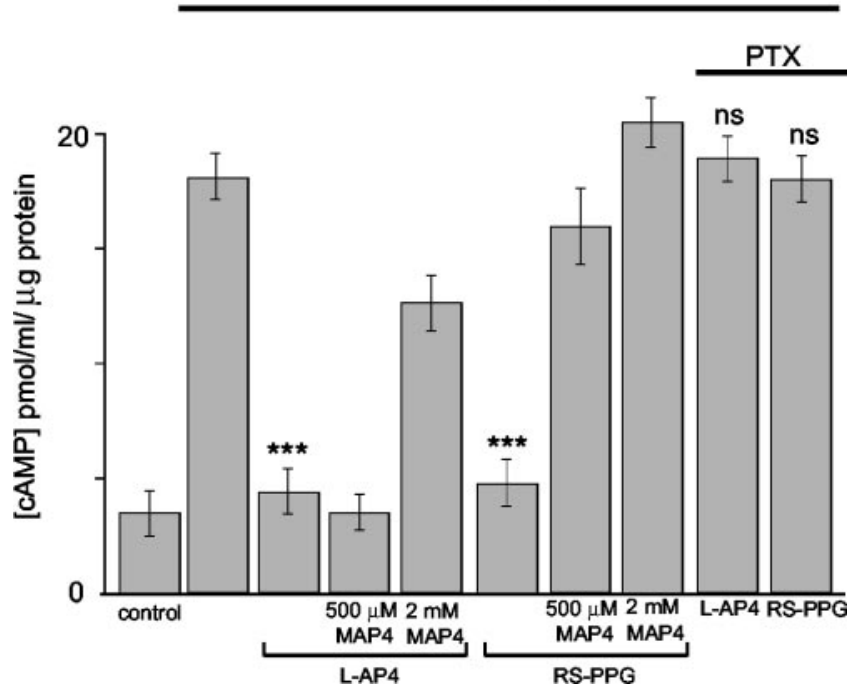

Figure 3. Inhibition of forskolin-induced cAMP accumulation in microglia by group III mGlu receptor agonists and receptor coupling to pertussis toxin-sensitive G-proteins. Microglia were treated with $100 \mu \mathrm{m}$ forskolin for $10 \mathrm{~min}$, followed by the group III mGlu receptor agonists L-AP-4 $(100 \mu \mathrm{M})$ or RS-PPG $(100 \mu \mathrm{M})$ with or without $500 \mu \mathrm{m}$ or $2 \mathrm{~mm}$ MAP4 for an additional 10 min. Control cells were not forskolin treated or exposed to group III mGlu receptor agonistsantagonists. Microglia were treated with PTX at $1 \mu \mathrm{g} / \mathrm{ml}$ for $22 \mathrm{hr}$ before the measurement of cAMP accumulation with the $\mathrm{mGlu}$ receptor agonists as above. Data are the mean $\pm S E M$ of a least three determinations. ${ }^{* *}$ Significance levels are shown when compared with forskolintreated cells $(p<0.005)$. ns, Not significant.

was used to antagonize the effects of $R S$-PPG, and 2 mM MAP4 was used to antagonize the effects of L-AP-4.

To determine whether microglial apoptosis induced by other known microglial activators could also be attenuated by stimulation of microglial group III mGlu receptors, we investigated the effects of A $\beta 25-35$ or LPS. At a concentration of $50 \mu \mathrm{M}, \mathrm{A} \beta 25-35$ induced $39 \pm 0.69 \%$ apoptosis after $24 \mathrm{hr}$ exposure (Fig. $4 \mathrm{C}$ ). This apoptosis could be significantly attenuated to control levels by L-AP-4 or RS-PPG. Furthermore, the group III mGlu receptor antagonist MAP4 could abrogate this effect, suggesting that the protective effects of group III mGlu receptor stimulation are specific. Similarly, exposure of microglia to $1 \mu \mathrm{g} / \mathrm{ml} \mathrm{LPS} \mathrm{for} 24 \mathrm{hr}$ induced microglial apoptosis to $47 \pm 2.88 \%$ (Fig. $4 D$ ). This apoptosis was significantly attenuated to control levels by L-AP-4 or $R S$-PPG. Furthermore, MAP4 could prevent the protection by the group III agonists, suggesting that the effects of L-AP-4 or $R S$-PPG are specific.

\section{Stimulation of group III mGlu receptors on microglia does not produce a neurotoxic phenotype}

To determine whether direct stimulation of microglial group III mGlu receptors in the absence of other microglial activators produced a neurotoxic microglial phenotype, neurons were incubated with medium from microglia that had been exposed to mGlu receptor agonists and/or antagonists only. Conditioned medium from microglia incubated for $24 \mathrm{hr}$ with L-AP-4 or $R S$ PPG with or without MAP4 was not neurotoxic (Fig. 5A), although the microglia may be activated, as evidenced by increased ED1 staining (Table 1, middle and bottom). Conditioned medium from microglia incubated with MAP4 alone for $24 \mathrm{hr}$ was also not neurotoxic (Fig. 5A). These results suggest that stimulation of group III mGlu receptors on microglia does not lead to a neurotoxic microglial activation. Because MAP4 alone did not induce a
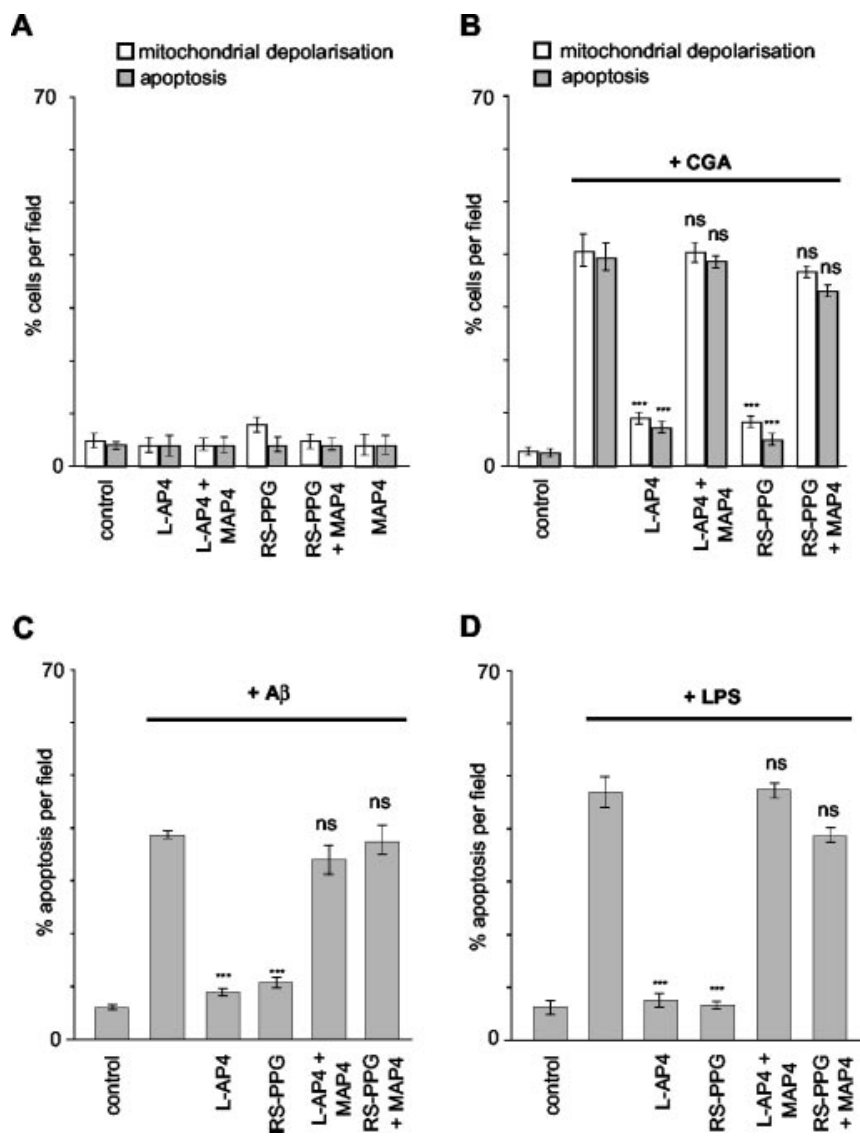

Figure 4. Activation of group III mGlu receptors on microglia can prevent microglial mitochondrial depolarization and cellular apoptosis. Primary cultured rat microglia were exposed to the specific group III mGlu receptor agonists (L-AP-4 at $100 \mu \mathrm{M}$ and RS-PPG at $100 \mu \mathrm{M}$ ) and antagonists (MAP4, $2 \mathrm{~mm}$ alone or in combination with L-AP-4 or $500 \mu \mathrm{m}$ in combination with $R S-P P G)$ without other microglial activators $(A)$, with the microglial activator $(G A$ at $50 \mathrm{~nm}(B)$, with the microglial activator $A \beta 25-35$ at $50 \mu \mathrm{M}(C)$, and with the microglial activator LPS at 1 $\mu \mathrm{g} / \mathrm{ml}(D)$. After $24 \mathrm{hr}$, the number of cells with depolarized mitochondria (determined by JC-1 staining) $(A, B)$ and those exhibiting apoptotic nuclei (as indicated by Hoechst 33342 staining) were counted $(A-D)$. Stimulation of group III $\mathrm{mGlu}$ receptors without other activators did not significantly increase microglial depolarization and apoptosis ( $A$ ). CGA-induced mitochondrial depolarization and apoptosis was significantly reduced by $\mathrm{L}-\mathrm{AP}-4$ or $R S-\mathrm{PPG}(B)$, as was $A \beta 25$ 35-induced apoptosis $(C)$ and LPS-induced apoptosis $(D)$. The effects of the group III mGlu receptor agonists could be abated by the group III mGlu receptor antagonist MAP4. Data are the mean \pm SEM of at least four determinations. Significance levels are shown when compared with unstimulated microglia (control; $A$ ) or microglia stimulated with CGA alone $(B)$, microglia stimulated with $A \beta 25-35$ alone $(C)$, or microglia stimulated with $L P S$ alone $(D){ }^{* * *} p<0.005$. $n s$, Not significant.

neurotoxic phenotype, these data also suggest that there is no tonic stimulation of these receptors in nonstimulated microglia, which may suppress their neurotoxicity. No increased neuronal death was observed at $48 \mathrm{hr}$ of incubation with microglial conditioned medium, suggesting that these effects are not attributable to a delayed apoptotic cascade (data not shown).

To determine how modulation of microglial group III mGlu receptors affects the neurotoxicity of microglia activated with CGA, we exposed cultured cerebellar granule neurons to conditioned medium from microglia treated as above. Conditioned medium from CGA-stimulated microglia induces death of cultured cerebellar granule neurons by apoptosis (Kingham et al., 1999). At $24 \mathrm{hr}$, neuronal apoptosis was $\sim 50 \%$ of the total cells (Fig. 5B), rising to $95 \%$ at $48 \mathrm{hr}$. Because of the loss of cell adhesion as the number of apoptotic cells increased, we measured 


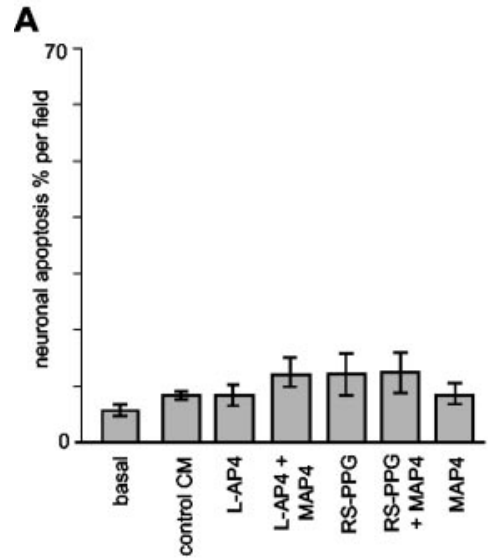

D

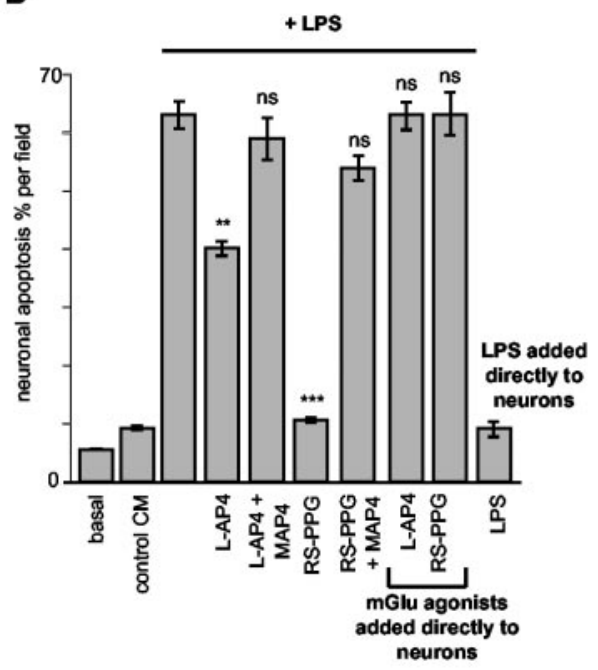

B

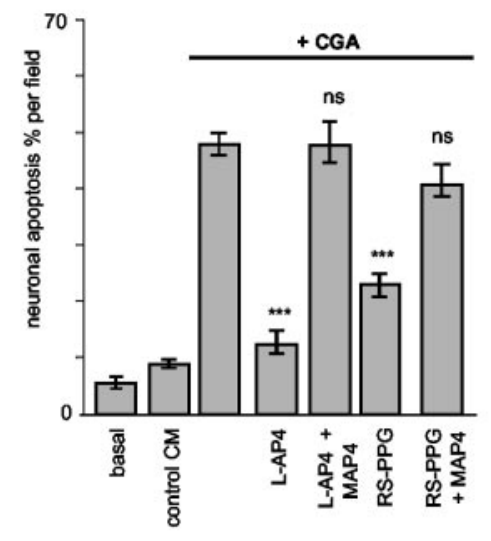

$\mathbf{E}$

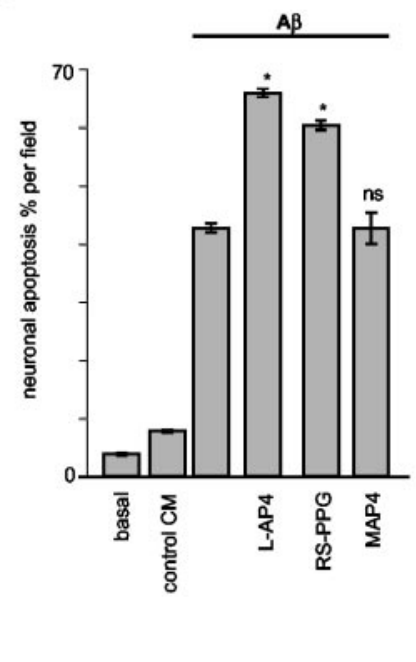

C

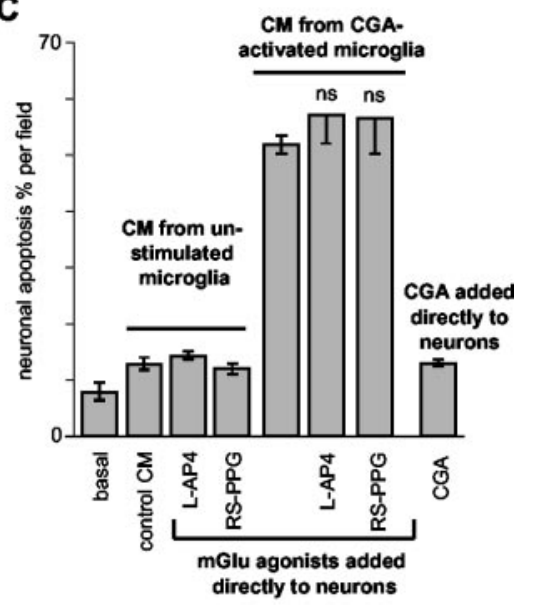

$\mathbf{F}$

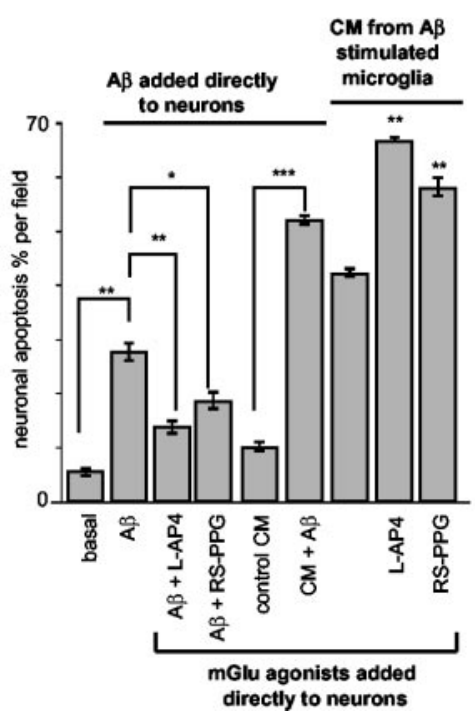

Figure 5. Stimulation of microglial group III $\mathrm{mGlu}$ receptors is not neurotoxic and protects neurons from microglial activation-induced neurotoxicity. Cerebellar granule neurons were incubated with conditioned medium from microglia exposed for $24 \mathrm{hr}$ to mGlu receptor agonists (100 $\mu \mathrm{ML}-\mathrm{AP}-4$ and $100 \mu \mathrm{m} \mathrm{RS-PPG)}$ and/or antagonists (MAP4 at $500 \mu \mathrm{m}$ unless used alone or in combination with L-AP-4 when $2 \mathrm{~mm}$ was used) with or without $50 \mathrm{~nm} \mathrm{(GA,} 1 \mu \mathrm{g} / \mathrm{ml}$ LPS, or $50 \mu \mathrm{m} \mathrm{A} \beta 25-35$. Apoptosis was measured in the neuronal cultures by Hoechst 33342 staining $24 \mathrm{hr}$ after incubation with microglial conditioned medium. A, Stimulation or inhibition of microglial group III mGlu receptors in the absence of other microglial activators did not increase neuronal death above that in neuronal cultures exposed to conditioned medium from microglia without $\mathrm{mGlu}$ receptor agonists or antagonists (control $\mathrm{CM}$ ). basal refers to the apoptosis in neuronal cultures to which no conditioned medium was added. B, Conditioned medium from CGA-activated microglia induced neuronal death, which could be reduced by activation of microglial group III mGlu receptors with L-AP-4 or RS-PPG. This reduction could be attenuated if the microglia were exposed to the group III mGlu receptor antagonist MAP4. Significance levels are shown for comparisons with the level of apoptosis induced in neurons exposed to conditioned medium from CGA-stimulated microglia. C, Neuronal apoptosis was not induced after $24 \mathrm{hr}$ exposure to conditioned medium from unstimulated microglia and direct application to the neuronal cultures of L-AP-4 or RS-PPG. Neuronal apoptosis induced by medium from CGA-activated microglia was not decreased by direct application of the mGlu receptor agonists to the neuronal cultures. Significance levels are shown for comparisons with control $C M$ (conditioned medium from unstimulated microglia), for $C M$ from unstimulated microglia, or with conditioned medium from microglia exposed to CGA alone in CM from CGA-activated microglia.D, Conditioned medium from microglia exposed to LPS induced neuronal apoptosis, which could be attenuated if the microglia were coexposed to L-AP-4 or RS-PPG. This protection could be reversed by exposure of the microglia to MAP4. Direct application of the mGlu agonists to the neurons only did not attenuate neuronal apoptosis induced by conditioned medium from LPS-stimulated microglia ( $m$ Glu agonists added directly to neurons). Significance levels are shown for comparisons with the level of apoptosis induced in neurons exposed to conditioned medium from LPS-stimulated microglia. $E$, Conditioned medium from A $\beta 25$-35-stimulated microglia produces neuronal apoptosis, which cannot be attenuated by coexposure of the microglia to group III mGlu receptor agonists. $F, A \beta 25-35$ added directly to neurons with $(C M+A \beta)$ or without $(A \beta)$ conditioned medium from nonstimulated microglia (control $C M$ ) produces neuronal apoptosis. This apoptosis could be attenuated by direct addition of the mGlu receptor agonists to the neurons. Significance levels are compared as shown. In contrast, neuronal apoptosis induced by conditioned medium from microglia stimulated with $\mathrm{A} \beta 25-35$ (CM from $A \beta$ stimulated microglia) was not attenuated by direct addition to the neurons of group III mGlu receptor agonists. Significance levels are shown for the level of apoptosis induced in neurons exposed to conditioned medium from A $\beta 25$-35-stimulated microglia. In all cases, data are the mean \pm SEM of at least four determinations. ns, Not significant. ${ }^{*} p<0.01 ;{ }^{* *} p<0.05 ;{ }^{* * *} p<0.005$.

apoptosis at $24 \mathrm{hr}$ because cell numbers were more consistent than observed at extended time points. Neither CGA directly added to the cerebellar cultures (Fig. 5C) nor conditioned medium from nonstimulated microglia (Fig. $5 A-C$ ) had any significant deleterious effect on neuronal survival, indicating that the presence of microglia and CGA together were required for neurotoxicity (Kingham et al., 1999). To determine how exposure of microglia to agonists or antagonists of group III mGlu receptors modulated subsequent neurotoxicity after CGA stimulation, neuronal cultures were incubated with conditioned medium from microglia exposed to mGlu receptor agonists and/or antagonists during CGA stimulation, and the level of apoptosis induced in neurons exposed to microglial conditioned medium for $24 \mathrm{hr}$ was assessed by Hoechst 33342 staining. 
Costimulation of microglial group III mGlu receptors in the presence of a microglial activator protects against activatorinduced microglial neurotoxicity

We and others have shown previously that conditioned medium from microglia activated with CGA is neurotoxic (CiesielskiTreska et al., 1998; Kingham et al., 1999; Taylor et al., 2002). Thus, we determined whether stimulation of microglial group III mGlu receptors could modulate this neurotoxicity. Medium from microglia incubated with the group III agonists L-AP-4 or $R S$-PPG together with $50 \mathrm{~nm}$ CGA resulted in significant attenuation of neuronal apoptosis compared with medium from microglia exposed to CGA alone (Fig. $5 B$ ). This neuroprotection was prevented if the microglia were also exposed to MAP4 (500 $\mu \mathrm{M}$ in combination with RS-PPG) (Fig. 5B). Higher concentrations of MAP4 were able to reverse the L-AP-4 effect; thus, 1 mM MAP4 together with CGA and L-AP-4 produced levels of neuronal apoptosis of $38.77 \pm 1.21 \%$, whereas $2 \mathrm{~mm} \mathrm{MAP} 4$ together with CGA and L-AP-4 produced levels of apoptosis of $53.37 \pm 5.87 \%$, not significantly different from the apoptosis induced with CGA alone $(54.40 \pm 2.54 \%)$.

The observed changes in neuronal apoptosis were attributable to the different microglial conditioned media because direct application of either CGA or mGlu receptor agonists and antagonists to neuronal cultures did not increase neuronal apoptosis above control levels (Fig. 5C). Furthermore, when conditioned medium from control microglia or from microglia stimulated with CGA was added to neuronal cultures followed by direct application of either L-AP-4 or RS-PPG to the neurons, there was no significant modulation of apoptosis (either increased or decreased) (Fig. 5C). In particular, this suggests that L-AP-4 or RSPPG did not exert their neuroprotective effects by a direct activation of group III mGlu receptors on neuronal cells but rather by modulating the neurotoxicity of the microglia. Thus, the attenuation of CGA-induced microglial neurotoxicity by microglial group III mGlu receptor activation was not attributable to carryover of the agonists in the microglial conditioned medium.

\section{LPS-induced microglial neurotoxicity is attenuated by activation of microglial group III mGlu receptors}

To determine whether the observed inhibition of CGA-induced microglial neurotoxicity was also seen for other microglial activators, we activated microglia with LPS $(1 \mu \mathrm{g} / \mathrm{ml})$ and determined the subsequent neurotoxicity. Conditioned medium from LPS-stimulated microglia was neurotoxic, and this was attributable to microglial neurotoxicity rather than a direct effect of LPS on the neurons (Fig. 5D). This neurotoxicity could be attenuated if the microglia were concurrently exposed to the group III mGlu receptor agonists $\mathrm{L}-\mathrm{AP}-4$ or $R S$-PPG, with the latter agonist being more potent than in the case of CGA-induced microglial neurotoxicity. The protective effects of the group III mGlu receptor agonists could be prevented by the group III mGlu receptor antagonist MAP4. To confirm that the effects of the agonists were not attributable to a direct effect on the cerebellar neurons, the neurons were exposed to conditioned medium from LPS-treated microglia and L-AP-4 or RS-PPG added directly to the neurons. In this case, the agonists did not protect against LPS-induced microglial neurotoxicity (Fig. 5D).

A $\beta 25-35$-induced microglial neurotoxicity is not attenuated
by activation of microglial group III mGlu receptors
Contrary to our findings with CGA and LPS, the neurotoxicity of
conditioned medium from microglia exposed to A $\beta 25-35$ was
not attenuated if the microglia were also preincubated with the group III agonists L-AP-4 or RS-PPG (Fig. $5 E$ ). To investigate this further, we added $A \beta 25-35$ directly to the cerebellar neurons with or without control microglial conditioned medium and found that this was neurotoxic (Fig. $5 F$ ). Furthermore, direct addition of the group III agonists to cerebellar neurons exposed to conditioned medium from A $\beta 25$-35-treated microglia did not protect the neurons. Therefore, unlike LPS or CGA, A $\beta 25-35$ may have a direct neurotoxic effect if this peptide is carried over into the conditioned medium. Thus, we added both $A \beta 25-35$ and the group III agonists directly to the neurons. We found, in accordance with other researchers, that there was significant protection afforded to the neurons (Fig. $5 F$ ). This suggests that the conditioned medium from microglia treated with A $\beta 25-35$ contains additional toxins to which the group III mGlu receptor agonists are not neuroprotective when these agonists are added either to the microglia or directly to the neurons.

\section{Group III mGlu receptor stimulation on microglial in coculture with neurons is neuroprotective}

Our results indicate that costimulation of group III mGlu receptors on microglia in the presence of a neurotoxic activator (CGA or LPS) can depress the subsequent neurotoxicity of the conditioned medium. The design of these experiments demonstrated that the neurotoxins produced from CGA-stimulated microglia are stable in solution and that activation of group III mGlu receptors decreases the potency of these stable toxins. To investigate whether modulation of neurotoxin efficacy from the microglia by group III mGlu receptor activation extends to that for nonstable toxins such as nitric oxide (NO), we cocultured neurons with microglia that had been activated with CGA or LPS in the presence of group III mGlu receptor agonists. Similar results for microglial and neuronal apoptosis after CGA activation and mGlu receptor modulation were obtained when microglia and neurons were grown in coculture (Fig. 6). This suggests that, even if $\mathrm{NO}$ is being produced, the protection afforded by activation of group III mGlu receptors on microglia must involve modulation of stable neurotoxins or promote the formation of stable neuroprotective substances from the microglia.

\section{Discussion}

Our results show for the first time that primary cultured microglia from rat brain express group III mGlu receptors. We were able to detect mRNA for mGlu4, mGlu6, and mGlu8 but not mGlu7. It is of interest that microglia express mGlu6; previously, mGlu6 expression was thought to be restricted to the retina (Nakajima et al., 1993; Pin and Duvoisin, 1995) but has been shown recently to be expressed in hippocampal, cortical, and cerebellar granule neurons (Janssens and Lesage, 2001), as well as in cortical-glial cultures (Faden et al., 1997). The expression of mRNA for mGlu4 and mGlu8 in microglia differs from the findings of Biber et al. (1999), who reported only mGlu5 and very faint expression of mGlu1 and mGlu6. Because the microglial culture conditions in this paper are different from those of Biber et al. (1999), it is conceivable that these changes reflect this. For example, we use acute dissociation with short (1-2 DIV) culture periods in high $\mathrm{KCl}$ to allow for medium transfer to neurons. Differences in culture conditions as well as age have been shown to alter the expression of mGlu receptor mRNA (Catania et al., 1994; Schools and Kimelberg, 1999). In other glial cells, such as hippocampal astrocytes from young rats, the expression of mGlu4 and mGlu8 was not observed (Schools and Kimelberg, 1999), the predominant subtypes expressed on these cells being mGlu3 and mGlu5. The presence of receptor protein reflected the mGlu re- 


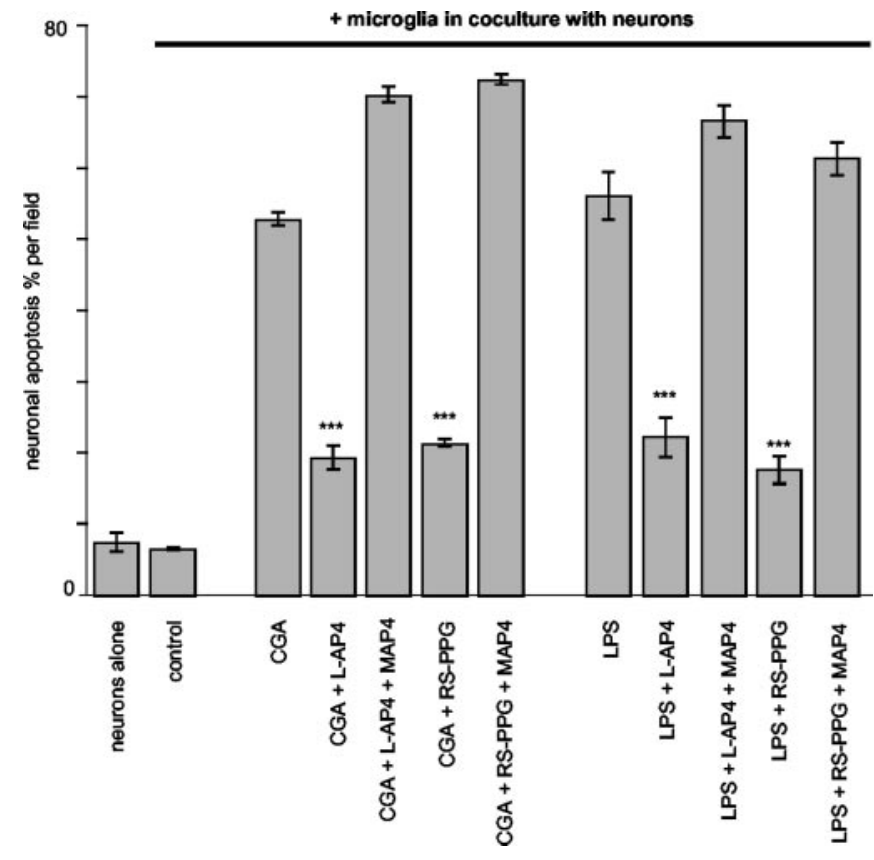

Figure 6. Activation of microglial group III mGlu receptors inhibits the release of soluble, stable neurotoxins. Neuronal apoptosis was measured with Hoechst 33342 staining after $24 \mathrm{hr}$ microglial-neuronal coculture. Microglia without stimulation in coculture with neurons (control) did not induce apoptosis above that in primary cultures of cerebellar granule neurons cultured alone (neurons alone). Addition of (GA ( $50 \mathrm{~nm}$ ) produced significantly elevated levels of neuronal apoptosis when compared with control. The group III mGlu receptor agonists L-AP-4 $(100 \mu \mathrm{M})$ or RS-PPG (100 $\mu \mathrm{m})$ significantly reduced (GA evoked apoptosis to levels observed in control. This protection by L-AP-4 or RS-PPG could be attenuated by coexposure of the cocultures with MAP4 (2 mM with L-AP-4 or $500 \mu \mathrm{m}$ with RS-PPG). Addition of LPS $(1 \mu \mathrm{g} / \mathrm{ml})$ produced significantly elevated levels of neuronal apoptosis when compared with control, which could be attenuated by L-AP-4 or RS-PPG. The neuroprotection afforded by the mGlu receptor agonists could be prevented by coexposure with MAP4. ${ }^{* *}$ Significance levels are shown for comparisons with the apoptosis induced with the microglial activator, e.g., CGA or LPS alone $(p<0.005)$. Data are the mean \pm SEM of at least four determinations.

ceptor mRNA expression; thus, immunolocalization indicated the presence of receptor protein for mGlu, mGlu6, and mGlu8 but not mGlu7.

The finding that forskolin-induced cAMP accumulation in microglia can be prevented by L-AP-4 or RS-PPG (and reversed by MAP4) suggests that group III mGlu receptors on microglia are negatively coupled to adenylate cyclase. This is consistent with findings for other cell types expressing these receptors (Conn and Pin, 1997). It is of interest that a higher concentration of MAP4 was required to reverse the L-AP-4-induced inhibition of forskolin-evoked cAMP accumulation than was required for $R S$-PPG. This was also the case for the effects on microglial activation and neurotoxicity. Furthermore, the ability of pertussis toxin to prevent the mGlu receptor agonist-evoked inhibition of forskolin-induced cAMP production suggests that microglial group III mGlu receptors are coupled to a $\mathrm{G}_{\mathrm{i}}$-type of $\mathrm{G}$-protein, again consistent with findings for these receptors in other cell types (Conn and Pin, 1997). However, this does not rule out the involvement of other transduction pathways to which these receptors may be coupled in microglia; for example, in other cells, mGlu6 may couple to a cGMP phosphodiesterase (Shiells and Falk, 1992).

Microglia exposed to the group III mGlu receptor agonists L-AP-4 or RS-PPG without other stimulation did not show enhanced mitochondrial depolarization and apoptosis, suggesting that the microglia did not become overly activated when these receptors are stimulated This is reflected in the lower ED1 staining observed with L-AP-4 or RS-PPG compared with that observed after CGA or LPS stimulation. When present with CGAstimulation, L-AP-4 or RS-PPG prevented CGA-mediated depolarization and apoptosis. We showed previously that mitochondrial depolarization precedes apoptosis after CGA stimulation of microglia (Kingham and Pocock, 2000), and it is thus likely that the inhibition of mitochondrial depolarization by L-AP-4 or RS-PPG modulates downstream apoptotic cascades. These findings also suggest that modulation of group III mGlu receptors appears extremely effective at preventing CGA-induced microglial mitochondrial depolarization and apoptosis. In addition, activation of group III mGlu receptors was able to attenuate LPS- and A $\beta 25$-35-induced microglial apoptosis.

In terms of the specificity of responses observed here, L-AP-4 has been shown to be a selective agonist of group III mGlu receptors, being more potent at mGlu4, mGlu6, and mGlu8 receptors than at mGlu7 receptors (Okamoto et al., 1994; Schoepp et al., 1999). RS-PPG is a selective agonist of group III mGlu receptors and, in recombinant cell lines expressing human group III mGlu receptors, has a higher potency for mGlu8a than mGlu6 or mGlu4a and lowest potency at mGlu7b (Gasparini et al., 1999). The exact splice variants of the group III mGlu receptors expressed in microglia remain to be determined because the antibodies, with the exception of mGlu4a, react with all the splice variants. The mRNA rat primer for mGlu 4 would amplify both $4 \mathrm{a}$ and $4 \mathrm{~b}$. Whereas the mRNA rat primer is specific for mGlu7a, the mGlu7 antibody reacts with mGlu7a and mGlu7b, and, because staining for this was not detected, we can rule out the possibility of one of these being expressed in the microglia. Furthermore, we were unable to detect any staining with an antibody to mGlu7b (data not shown). Splice variants for mGlu6 or mGlu8 have so far not been observed elsewhere in other cell types.

The stimulation of microglial group III mGlu receptors does not lead to the production of neurotoxins in itself, suggesting that, as well as preventing mitochondrial stress and apoptosis of the microglia, activation of group III mGlu receptors does not simply prolong the life of a neurotoxic microglial cell. Furthermore, the activation of group III mGlu receptors on microglia appeared to protect the neurons against CGA- or LPS-induced microglial neurotoxicity. Whether this neuroprotection is attributable to the inhibition of microglial toxin production or the stimulated release of additional neuroprotective substances remains to be determined. In astrocytes, mGlu receptor stimulation may lead to the release of neurotrophic factors, such as TGF- $\beta$ (Bruno et al., 1997, 1998).

CGA triggers the production of NO in microglia mediated by inducible NO synthase (Taupenot et al., 1996; Kingham et al., 1999). However, conditioned medium from CGA-stimulated microglia does not mediate NO- or peroxynitrite-dependent neuronal death (Ciesielski-Treska et al., 1998; Kingham et al., 1999). In support of this, similar results were obtained when microglia and neurons were grown in coculture (present study; Taylor et al., 2002). Furthermore, the neurotoxicity of LPSstimulated microglia was also the same in coculture as with conditioned medium. These data suggest that stimulation of microglia can induce neuronal death via the release of soluble, nonlabile toxins that may act as agonists of the NMDA receptor (Kingham et al., 1999).

Whereas agonists of group III mGlu receptors inhibited microglial neurotoxicity when the microglia were stimulated with CGA or LPS, this was not the case for $A \beta 25-35$. If the neurotoxicity of conditioned medium from $A \beta 25-35$-stimulated micro- 
glia were attributable to a direct neurotoxicity of the $\mathrm{A} \beta 25-35$ (carried over in the medium), as reported previously (Schorzielli et al., 1996), we might expect some attenuation of this neurotoxicity by the direct addition of the mGlu agonists to the neurons. However, this was not the case. In line with the findings of Schorzielli et al. (1996), we found that the direct addition of $A \beta 25-35$ is toxic to neurons and, furthermore, that the group III mGlu receptor agonists attenuated this neurotoxicity. These data suggest, therefore, that the conditioned medium from microglia exposed to $A \beta 25-35$ is unlikely to contain significant levels of $A \beta 25-35$ to induce direct neurotoxicity. Rather, the medium contains additional microglial neurotoxins to which the group III mGlu receptor agonists are not neuroprotective when these receptor agonists are added either to the microglia or directly to the neurons.

Currently, we do not know how stimulation of group III mGlu receptors on microglia may act to suppress CGA- or LPS-induced neurotoxicity or toxicity to the microglia. Recently, activation of group III mGlu receptors on astrocytes was shown to decrease chemokine production (Besong et al., 2002). In other systems, activation of mGlu receptors, particularly groups I or III, can prevent NO-induced programmed cell death in neurons (Vincent and Maiese, 2000). Interestingly, it has also been reported that group II mGlu receptor agonists were unable to prevent NO-induced neuronal programmed cell death because they do not prevent phosphatidylserine externalization, although they can preserve genomic DNA (Vincent and Maiese, 2000), suggesting differential regulation of cellular apoptosis by different classes of mGlu receptor. We showed previously that agonists of microglial group II mGlu receptors can stimulate microglial apoptosis and induce a neurotoxic phenotype (Taylor et al., 2002), suggesting fundamental differences in the downstream signaling cascades triggered by group II and group III mGlu receptors on microglia. The differential regulation of, for example, ligand- and voltage-gated ion channels, such as potassium or calcium channels, by groups II and III mGlu receptors has been shown for other cell types (for review, see Conn and Pin, 1997; De Blasi et al., 2001), suggesting that the precedence exists for such differences between these two groups. The neuroprotective effect of the activation of group III mGlu receptors may also lie in the ability of this receptor to inhibit glutamate release from microglia, as has been shown in neurons (Conn and Pin, 1997).

In conclusion, the present results provide evidence that group III mGlu receptors expressed by microglia are involved in the modulation of signaling pathways leading to microglial activation and subsequent neurotoxicity after exposure to CGA, LPS, and possibly A $\beta 25-35$. Suppression of microglial activation by selective modulation of group III microglial mGlu receptors may be a putative therapeutic strategy in Alzheimer's disease and other neurodegenerative diseases in which microglial reactivity is implicated.

\section{References}

Besong G, Battaglia G, D’Onfrio M, Di Marco R, Ngomba RT, Storto M, Castiglione M, Mangano K, Busceti CL, Nicoletti FR, Bacon K, Tusche M, Valenti O, Conn PJ, Bruno V, Nicoletti F (2002) Activation of group III metabotropic glutamate receptors inhibits the production of RANTES in glial cell cultures. J Neurosci 22:5403-5411.

Biber K, Laurie DJ, Berthele A, Sommer B, Tolle TR, Gebicke-Harter PJ, van Calker D, Boddeke HW (1999) Expression and signaling of group I metabotropic glutamate receptors in astrocytes and microglia. J Neurochem 72:1671-1680.

Bruno V, Sureda FX, Storto M, Casabona G, Caruso A, Knöpfel T, Kuhn R, Nicoletti F (1997) The neuroprotective activity of group II metabotropic glutamate receptors requires new protein synthesis and involves a glial-neuronal signaling. J Neurosci 17:1891-1897.
Bruno V, Battaglia G, Casabona G, Copani A, Caciagli F, Nicoletti F (1998) Neuroprotection by glial metabotropic glutamate receptors is mediated by transforming growth factor- $\beta$. J Neurosci 18:9594-9600.

Catania MV, Landwehrmeyer GB, Testa CM, Standaert DG, Penney Jr JB, Young AB (1994) Metabotropic glutamate receptors are differentially regulated during development. Neuroscience 61:481-495.

Chomczynski P, Sacchi N (1987) Single-step method of RNA isolation by acid guanidinium thiocyanate-phenol-chloroform extraction. Anal Biochem 162:156-159.

Ciesielski-Treska J, Ulrich G, Taupenot L, Chasserot-Golaz S, Corti A, Aunis D, Bader M-F (1998) Chromogranin A induces a neurotoxic phenotype in brain microglial cells. J Biol Chem 273:14339-14346.

Conn PJ, Pin JP (1997) Pharmacology and functions of metabotropic glutamate receptors. Annu Rev Pharmacol Toxicol 37:205-237.

Copelman CA, Cuzner ML, Groome N, Diemel LT (2000) Temporal analysis of growth factor mRNA expression in myelinating rat brain aggregate cultures: increments in CNTF, FGF-2. IGF-1 and PDGF-AA mRNA are induced by antibody-mediated demyelination. Glia 30:342-351.

De Blasi A, Conn PJ, Pin J-P, Nicoletti F (2001) Molecular determinants of metabotropic glutamate receptor signalling. Trends Pharmacol Sci 22:114-120.

Evans GJO, Pocock JM (1999) Modulation of neurotransmitter release by dihydropyridine-sensitive calcium channels involves tyrosine phosphorylation. Eur J Neurosci 11:279-292.

Faden AI, Ivanova SA, Yakovlev AG, Mukhin AG (1997) Neuroprotective effects of group III mGluR in traumatic neuronal injury. J Neurotrauma 14:885-895.

Gasparini F, Bruno V, Battaglia G, Lukic S, Leonhardt T, Inderbitzin W, Laurie D, Sommer B, Varney MA, Hess SD, Johnson EC, Kuhn R, Urwyler S, Sauer D, Portet C, Schmutz M, Nicoletti F, Flor PJ (1999) $(R, S)-4$ phosphonophenylglycine, a potent and selective group III metabotropic glutamate receptor agonist, is anticonvulsive and neuroprotective in vivo. J Pharmacol Exp Ther 289:1678-1687.

Janssens N, Lesage ASJ (2001) Glutamate receptor subunit expression in primary neuronal and secondary glial cultures. J Neurochem 77:1457-1474.

Kingham PJ, Pocock JM (2000) Microglial apoptosis induced by chromogranin $\mathrm{A}$ is mediated by mitochondrial depolarisation and the permeability transition but not by cytochrome c release. J Neurochem 74:1452-1462.

Kingham PJ, Cuzner ML, Pocock JM (1999) Apoptotic pathways mobilized in microglia and neurons as a consequence of chromogranin-A induced microglial activation. J Neurochem 73:538-547.

Klegeris A, McGeer PL (1997) $\beta$-Amyloid protein enhances macrophage production of oxygen free radicals and glutamate. J Neurosci Res 49:229-235.

Klegeris A, Walker DG, McGeer PL (1997) Regulation of glutamate in cultures of human monocytic THP-1 and astrocytoma U-373 MG cells. J Neuroimmunol 78:152-161.

Liu B, Wang K, Gao HM, Mandavilli B, Wang JY, Hong JS (2001) Molecular consequences of activated microglia in the brain: over activation induces apoptosis. J Neurochem 77:182-189.

McDonald DR, Brunden KR, Landreth GE (1997) Amyloid fibrils activate tyrosine kinase-dependent signalling and superoxide production in microglia. J Neurosci 17:2284-2294.

Munoz DG (1991) Chromogranin-A like immunoreactive neurites are major constituents of senile plaques. Lab Invest 64:826-832.

Munoz DG, Kobylinski L, Henry DD, George DH (1990) Chromogranin A-like immunoreactivity in the human brain: distribution in bulbar medulla and cerebral cortex. Neuroscience 34:533-543.

Nakajima Y, Iwakabe H, Akazawa C, Nawa H, Shigemoto R, Mzuno N, Nakanishi S (1993) Molecular characterization of a novel retinal metabotropic glutamate receptor mGluR6 with a high agonist selectivity for L-2amino-4-phosphonobutyrate. J Biol Chem 268:11868-11873.

Nicoletti F, Bruno V, Copani A, Casabona G, Knöfel T (1996) Metabotropic glutamate receptors: a new target for the therapy of neurodegenerative disorders? Trends Neurosci 19:267-271.

Okamoto N, Hori S, Akazawa C, Hayashi Y, Shigemoto R, Mizuno N, Nakanishi S (1994) Molecular characterisation of a new metabotropic glutamate receptor mGluR7 coupled to inhibitory cyclic AMP signal transduction. J Biol Chem 269:1231-1236.

Patrizio M, Levi G (1994) Glutamate production by cultured microglia: differences between rat and mouse, enhancement by lipopolysaccharide and lack of effect of HIV coat protein gp120 and depolarizing agents. Neurosci Lett 178:184-189. 
Piani D, Fontana A (1994) Involvement of the cysteine transport system $\mathrm{x}_{\mathrm{c}}$ in the macrophage induced glutamate dependent cytotoxicity to neurons. J Immunol 152:3578-3585.

Piani D, Frei K, Do KQ, Cuenod M, Fontana A (1991) Murine brain macrophages induced NMDA receptor mediated neurotoxicity in vitro by secreting glutamate. Neurosci Lett 133:159-162.

Piani D, Spranger M, Frei K, Schaffner A, Andriano F (1992) Macrophageinduced cytotoxicity of $N$-methyl-D-aspartate receptor positive neurons involves excitatory amino acids rather than reactive oxygen intermediates and cytokines. Eur J Immunol 22:2429-2436.

Pin J-P, Duvoisin R (1995) The metabotropic glutamate receptors: structure and functions. Neuropharmacology 34:1-26.

Salvioli S, Ardizzoni A, Franceschi C, Cossarizza A (1997) JC-1, but not DiOC6(3) or rhodamine 123, is a reliable fluorescent probe to assess $\Delta \psi \mathrm{m}$ changes in intact cells: implications for studies on mitochondrial functionality during apoptosis. FEBS Lett 411:77-82.

Schoepp DD, Jane DE, Monn JA (1999) Pharmacological agents acting at subtypes of metabotropic glutamate receptors. Neuropharmacology 38: 1431-1476.

Schools GP, Kimelberg HK (1999) mGluR3 and mGluR5 are the predominant metabotropic glutamate receptor mRNAs expressed in hippocampal astrocytes acutely isolated from young rats. J Neurochem 58:533-543.

Schorzielli A, Meucci O, Florio T, Fattore M, Forloni G, Salmona M, Schettini $\mathrm{G}$ (1996) A $325-35$ alters calcium homeostasis and induces neurotoxicity in cerebellar granule cells. J Neurochem 66:1995-2003.

Shiells RA, Falk G (1992) The glutamate-receptor linked cGMP cascade of retinal on-bipolar cells is pertussis and cholera toxin-sensitive. Proc R Soc Lond B Biol Sci 247:17-20.

Shigemoto R, Kinoshita A, Wada E, Nomura S, Ohishi H, Takada M, Flor PJ, Neki A, Abe T, Nakanishi S, Mizuno N (1997) Differential presynaptic localization of metabotropic glutamate receptor subtypes in the rat hippocampus. J Neurosci 17:7503-7522.

Streit WJ (1990) An improved staining method for rat microglial cells using the lectin from Griffonia simplicifolia (GSA IB4). J Histochem Cytochem 38:1683-1686.

Taupenot L, Ciesielski-Treska J, Ulrich G, Chasserot-Golaz S, Aunis D, Bader M-F (1996) Chromogranin A triggers a phenotypic transformation and the generation of nitric oxide in brain microglial cells. Neuroscience 72:377-389.

Taylor DL, Diemel LT, Cuzner ML, Pocock JM (2002) Activation of group II metabotropic glutamate receptors underlies microglial reactivity and neurotoxicity following stimulation with peptides upregulated in Alzheimer's disease. J Neurochem 82:1179-1191.

Vincent AM, Maiese K (2000) The metabotropic glutamate system promotes neuronal survival through distinct pathways of programmed cell death. Exp Neurol 166:65-82.

Yan G-M, Ni BH, Weller M, Wood KA, Paul SM (1994) Depolarisation or glutamate-receptor activation blocks apoptotic cell death of cultured cerebellar granule neurons. Brain Res 656:43-51.

Yasuhara O, Kawamata T, Aimi Y, McGeer EG, McGeer PL (1994) Expression of chromogranin $\mathrm{A}$ in lesions in the central nervous system from patients with neurological diseases. Neurosci Lett 170:13-16. 